\title{
Molecular characterization of enterotoxigenic Escherichia coli toxins and colonization factors in children under five years with acute diarrhea attending Kisii Teaching and Referral Hospital, Kenya
}

Erick Kipkirui ${ }^{1 *}$, Margaret Koech ${ }^{1}$, Abigael Ombogo ${ }^{1}$, Ronald Kirera ${ }^{1}$, Janet Ndonye${ }^{1}$, Nancy Kipkemoi ${ }^{1}$, Mary Kirui ${ }^{1}$, Cliff Philip ${ }^{1}$, Amanda Roth ${ }^{1,2}$, Alexander Flynn², Elizabeth Odundo ${ }^{1}$, Janeth Kombich ${ }^{3}$ and Ibrahim Daud ${ }^{1}$

\begin{abstract}
Background: Enterotoxigenic Escherichia coli (ETEC) is one of the leading causes of infectious diarrhea in children. There are no licensed vaccines against ETEC. This study aimed at characterizing Escherichia coli for ETEC enterotoxins and colonization factors from children $<5$ years with acute diarrhea and had not taken antibiotics prior to seeking medical attention at the hospital.

Methods: A total of 225 randomly selected archived E. coli strains originally isolated from 225 children with acute diarrhea were cultured. DNA was extracted and screened by multiplex polymerase chain reaction (PCR) for three ETEC toxins. All positives were then screened for 11 colonization factors by PCR.

Results: Out of 225 E. coli strains tested, 23 (10.2\%) were ETEC. Heat-stable toxin (ST) gene was detected in 16 (69.6\%). ETEC isolates with heat-stable toxin of human origin (STh) and heat-stable toxin of porcine origin (STp) distributed as $11(68.8 \%)$ and $5(31.2 \%)$ respectively. Heat-labile toxin gene (LT) was detected in $5(21.7 \%)$ of the ETEC isolates. Both ST and LT toxin genes were detected in 2 (8.7\%) of the ETEC isolates. CF genes were detected in 14 (60.9\%) ETEC strains with a majority having CS6 6 (42.9\%) gene followed by a combination of CFA/I + CS21 gene detected in 3 (21.4\%). CS14, CS3, CS7 and a combination of CS5 + CS6, CS2 + CS3 genes were detected equally in 1 (7.1\%) ETEC isolate each. CFA/I, CS4, CS5, CS2, CS17/19, CS1/PCFO71 and CS21 genes tested were not detected. We did not detect CF genes in 9 (39.1\%) ETEC isolates. More CFs were associated with ETEC strains with ST genes.
\end{abstract}

Conclusion: ETEC strains with ST genes were the most common and had the most associated CFs. A majority of ETEC strains had CS6 gene. In 9 (39.1\%) of the evaluated ETEC isolates, we did not detect an identifiable CF.

Keywords: Enterotoxigenic Escherichia coli, Toxins, Colonization factors, Acute diarrhea and children

\footnotetext{
* Correspondence: Cheruiyot.erick64@gmail.com

'United States Army Medical Research Directorate-Africa/Kenya, Nairobi, Kenya

Full list of author information is available at the end of the article
}

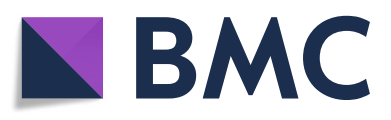

(- The Author(s). 2021 Open Access This article is licensed under a Creative Commons Attribution 4.0 International License, which permits use, sharing, adaptation, distribution and reproduction in any medium or format, as long as you give appropriate credit to the original author(s) and the source, provide a link to the Creative Commons licence, and indicate if changes were made. The images or other third party material in this article are included in the article's Creative Commons licence, unless indicated otherwise in a credit line to the material. If material is not included in the article's Creative Commons licence and your intended use is not permitted by statutory regulation or exceeds the permitted use, you will need to obtain permission directly from the copyright holder. To view a copy of this licence, visit http://creativecommons.org/licenses/by/4.0/ The Creative Commons Public Domain Dedication waiver (http://creativecommons.org/publicdomain/zero/1.0/) applies to the data made available in this article, unless otherwise stated in a credit line to the data. 


\section{Background}

Diarrhea is the second leading cause of death in infants and children in communities with poor sanitation and hygiene. Worldwide there are over 1.3 million deaths every year due to diarrhea. Up to $25 \%$ of deaths in children under the age of 5 years living in Africa and southeast Asia are due to diarrhea [1]. A recent study found bacteria to be the most common cause [2] with enterotoxigenic Escherichia coli (ETEC) ranked as the 8th leading cause of diarrhea mortality in 2016 among all age groups [3].. Indeed, ETEC is often the first bacterial pathogen that causes diarrhea in infants and children and is responsible for two to five diarrheal episodes during the first 3 years of life [4]. In addition, ETEC causes $80 \%$ of diarrhea in travelers from high income countries to low- and middle-income countries [5]. Thus, ETEC remains a major health threat to military soldiers deployed in endemic areas [6].

Enterotoxigenic E. coli is identified by its ability to produce plasmid encoded heat-labile (LT) and/or heatstable (ST) enterotoxins [7, 8]. Based on their host species, ST enterotoxins are further divided into heat-stable enterotoxins of porcine origin (STp) and heat-stable enterotoxins of human origin (STh). STp were originally isolated from domesticated pigs and has been implicated in human disease. STh is only produced by human ETEC isolates [9]. Both of these enterotoxins play a role in disrupting intestinal fluid homeostasis by increasing secretion of fluids and electrolytes through downstream activation of adenylate cyclase (by LT) or guanylate cyclase (by ST) in the small intestinal epithelial cells. When this process exceeds the absorption capacity of the bowel a watery diarrhea is passed [10]. A recent study has shown that LT contributes to ETEC pathogenesis by facilitating the initial adherence and subsequent intestinal colonization of murine and porcine intestinal mucosa. In this study it was reported that ETEC expressed F4ac fimbriae which enabled adhesion to the small intestine epithelial cells [11].

Colonization of the small intestine epithelial cells by ETEC is mediated by means of antigenically diverse thread like appendages (fimbriae) called colonization factors (CF) [7]. These factors are also referred to as colonization factor antigen $1(\mathrm{CFA} / 1)$ or coli surface (CS) antigen [8]. To date, more than 25 CFs have been identified and are classified into three families: (i) CFA/I group which include: CFA/I, CS1, CS2, CS4, CS14 and CS17 (ii) CS5 like group which include: CS5, CS7, CS18 and CS20 and (iii) a distinct group which include: CS3, CS6, CS10, CS11 and CS12 [12]. ETEC can express one or multiple CFs, however, some ETEC strains do not express any known CF $[12,13]$.

Multiple studies on diarrhea in Kenya have identified and reported ETEC as a major cause of diarrhea in children [14-19]. Due to a lack of capacity at most public laboratories to perform molecular testing, many of these studies do not characterize for STp and CFs in ETEC. Consequently, there are limited data on ETEC CF prevalence in many population demographics, including children under the age of 5 years. To address this knowledge gap, this study was conducted to characterize Escherichia coli isolates for ETEC enterotoxins and colonization factors from children under the age of 5 years presenting with acute diarrhea to the Kisii Teaching and Referral Hospital outpatient department.

\section{Materials and methods Study design and site}

This was a cross-sectional study nested in an ongoing enteric pathogen surveillance (EPS) study with in Kenya. In the EPS study, parents/guardians provided consent for their children's participation in the study as well as consent for the storage and future analysis of bacterial isolates. The study was conducted at the United States Army Medical Research Directorate-Africa (USAMRDA) Microbiology Hub Kericho (MHK) located in Kericho, Kenya.

\section{Study population}

The E. coli isolates characterized in this study were isolated from children enrolled in the EPS study protocol. The EPS study enrolls patients of all ages with acute diarrhea and asymptomatic age-matched controls in various outpatient and inpatient hospitals at Kenya Ministry of Health facilities. Stool specimens are transported to the MHK laboratory in Cary-Blair transport media and tested for common bacterial pathogens including E. coli, Vibrio spp., Salmonella spp., Shigella spp. and Campylobacter spp. by culture and biochemical analysis. Identified bacterial isolates are archived in a repository in 50\% glycerol at $80^{\circ} \mathrm{C}$. The E. coli isolates evaluated were isolated from children under the age of 5 years with acute diarrhea enrolled into the EPS study from May 2011 to June 2019 at Kisii Teaching and Referral Hospital (KTRH).

\section{Inclusion criteria}

From the parent EPS, study subject's inclusion criteria included: patients with acute diarrhea, defined as having three or more loose/watery stools within a 24-h period, lasting less than 14 days and have not taken antibiotics to treat the diarrhea prior to visiting the hospital. For this study the inclusion criteria were: $E$. coli isolates from case subjects under the age of 5 years and viable upon subculture. 


\section{Exclusion criteria}

The EPS study excluded individuals with chronic diarrhea (diarrhea lasting more than 2 weeks), those who had taken antibiotics and those unwilling to provide informed consent or give a stool specimen. For this study, additional exclusion criteria were: $E$. coli isolates from case subjects above 5 years of age and those not viable upon subculture.

\section{Sample size and sampling technique}

The sample size for this study was calculated using a single population proportion formula [20] with $95 \%$ confidence interval and $5 \%$ margin of error. The proportion of ETEC was taken to be $16.2 \%$ according to a study done in Kenya [14]. Thus, the minimum sample size was 208 children with $E$. coli isolated from them. We added 17 more children with $E$. coli to allow the study to cover an 8-year period. As a result, a total of 225 children each with $E$. coli were included in this study. Random sampling was used to select the archived $E$. coli isolates from the freezer using a register that is maintained for the EPS protocol.

\section{Laboratory analysis \\ Escherichia coli isolates revival}

The E. coli isolates utilized in this study were already identified using biochemical tests including Gram staining, catalase, oxidase, indole test, triple sugar iron agar and Voges Proskauer tests. The archived E. coli isolates were randomly selected from the MHK repository. The vial of the frozen bacterial stock was removed and inoculum picked using an inoculating needle, streaked on MacConkey agar (Becton Dickinson, Franklin Lakes, NJ, USA) and incubated overnight at $37^{\circ} \mathrm{C}$. All the E. coli isolates were viable upon subculture. E. coli lactosefermenting colonies on MacConkey agar were processed for DNA extraction.

\section{Bacterial DNA extraction}

Bacterial DNA template for ETEC enterotoxins and CF screening was extracted by boiling method [21] with slight modifications. Briefly, 5-10 E.coli colonies from MacConkey agar plates were picked with a sterile loop and suspended in $200 \mu \mathrm{l}$ of sterile nuclease free water and vortexed for $30 \mathrm{~s}$. The bacterial suspensions were boiled on a heat block at $100{ }^{\circ} \mathrm{C}$ for $20 \mathrm{~min}$ and centrifuged at $12,000 \mathrm{rpm}$ for $10 \mathrm{~min}$. The supernatant containing DNA was picked and stored at $-20^{\circ} \mathrm{C}$ prior to detection of ETEC toxins and CFs.

\section{Detection of ETEC enterotoxins genes}

ETEC virulence (eltB1, estA1 and estA2-4) genes were screened by an end point PCR using validated DNA primers (Table 1). The $25 \mu \mathrm{l}$ PCR reaction mixture contained $12.5 \mu \mathrm{l}$ of $2 \mathrm{X}$ DreamTaq Green PCR Master Mix (Thermo Scientific, Waltham, MA, USA), $0.5 \mu \mathrm{l}$ $(30 \mu \mathrm{M})$ each of forward and reverse primers for eltB1, estA1 and estA2-4 genes, $4.5 \mu \mathrm{l}$ of nuclease free water and $5 \mu \mathrm{l}$ of DNA template. The PCR reaction was performed on a Veriti ${ }^{\mathrm{im}}$ thermocycler (Applied Biosystems, Foster City, CA, USA) with an initial denaturation of $95^{\circ} \mathrm{C}$ for $2 \mathrm{~min}$, followed by 30 cycles of amplification $\left(95^{\circ} \mathrm{C}\right.$ for $1 \mathrm{~min}, 58^{\circ} \mathrm{C}$ for $30 \mathrm{~s}$ and $72^{\circ} \mathrm{C}$ for $1 \mathrm{~min}$ ), 1 cycle at $95^{\circ} \mathrm{C}$ for $1 \mathrm{~min}, 58^{\circ} \mathrm{C}$ for $30 \mathrm{~s}$ and a final extension step at $72{ }^{\circ} \mathrm{C}$ for $10 \mathrm{~min}$. Positive and negative controls were ETEC strain $\mathrm{H} 10407$ and nuclease-free water respectively.

\section{Detection of colonization factors genes}

$E$. coli isolates positive for one or multiple enterotoxins were further screened for detection of 11 colonization factors using gene-specific DNA primers (Table 1). Each PCR reaction final volume was $25 \mu \mathrm{l}$ containing $12.5 \mu \mathrm{l}$ of Dream Taq Green PCR Master Mix (Thermo Scientific, Waltham, MA, USA), $0.5 \mu \mathrm{l}$ of forward and reverse primer $(30 \mu \mathrm{M}), 3.5 \mu \mathrm{l}$ of nuclease free water and $5 \mu \mathrm{l}$ of DNA template for master mix I and III. For master mix II, $4.5 \mu \mathrm{l}$ was used instead of $3.5 \mu \mathrm{l}$ of nuclease free water. The PCR reactions were performed on a Veriti ${ }^{\mathrm{mx}}$ thermocycler (Applied Biosystems, Foster City, CA, USA) with an initial denaturation of $95^{\circ} \mathrm{C}$ for $2 \mathrm{~min}$, followed by 30 cycles of amplification $\left(95^{\circ} \mathrm{C}\right.$ for $1 \mathrm{~min}$, $60^{\circ} \mathrm{C}$ for $30 \mathrm{~s}, 72^{\circ} \mathrm{C}$ for $1 \mathrm{~min}$ ), one cycle of $95^{\circ} \mathrm{C}$ for 1 min, $60^{\circ} \mathrm{C}$ for $30 \mathrm{~s}$, and $72^{\circ} \mathrm{C}$ for $10 \mathrm{~min}$. Positive control strains were provided by the Naval Health Research Center (San Diego, CA, USA) and included: H10407 (cfaB), BANG10-SP (csaB and cssB), WS3294A (csuA1) $\mathrm{B} 2 \mathrm{C}$ (cstA, $\cot A$ and IngA), ETEC8/11(csfA), D022 $(c s v A)$, E24377A $(c s o A)$ and WS0115A (csbA-csdA). Nuclease-free water was used as negative control.

\section{Gel electrophoresis analysis}

The PCR amplicons were separated by electrophoresis on $2 \%$ agarose gel (Sigma Aldrich, St. Louis, MO, USA) stained using gel red (Biotium, San Francisco, CA, USA) and visualized under UV light using iBright gel documentation system (Applied Biosystems, Foster City, CA, USA).

\section{Data analysis}

The frequency of the type of enterotoxins and CFs detected was calculated. GraphPad Prism version 8.3 was used for statistical analysis with Fisher's exact test used for comparison between groups where appropriate. Differences were considered statistically significant if the $P$ value was less than 0.05 . 
Table 1 Primers used to detect ETEC enterotoxins and colonization factors [21]

\begin{tabular}{|c|c|c|c|c|}
\hline ETEC toxin/colonization factor & Target gene & Primer name & Sequence $\left(5^{\prime}\right.$ to $\left.3^{\prime}\right)$ & Amplicon size (bp) \\
\hline \multirow[t]{2}{*}{ LT } & eltB1 & LThF1 & CATAATGAGTACTTCGATAGAGGAAC & 402 \\
\hline & & LThR1 & GAAACCTGCTAATCTGTAACCATCC & \\
\hline \multirow[t]{2}{*}{ STp } & estA1 & STpF1 & ATGAAAAAGCTAATGTTGGCA & 239 \\
\hline & & STpR1 & TTAATAACATCCAGCACAGGCA & \\
\hline \multirow[t]{2}{*}{ STh } & estA2-4 & estA2-4F & AATTGCTACTATTCATGCTITCAGGAC & 133 \\
\hline & & estA2-4R & TCTITTCACCTTTCGCTCAGG & \\
\hline \multirow[t]{2}{*}{ CFA/I } & $c f a B$ & mpcr gp1F & TGAGTGCTTCWGCAGTAGAGA & 204 \\
\hline & & CFA1R & CAGCAAGTTTAACAATTACTTITTTAGT & \\
\hline \multirow[t]{2}{*}{ CS4 } & $\operatorname{csaB}$ & mpcr gp1F & TGAGTGCTTCWGCAGTAGAGA & 300 \\
\hline & & CS4R & AAGTCACATCTGCGGTTGATAGAG & \\
\hline \multirow[t]{2}{*}{ CS14 } & csuAl & mpcr gp1F & TGAGTGCTTCWGCAGTAGAGA & 357 \\
\hline & & CS14R & TACTATTCGAAACACCTGCCG & \\
\hline \multirow[t]{2}{*}{ CS6 } & $\operatorname{css} B$ & CssBCS6F & GGAGTGGTAAATGCAGGAAACT & 416 \\
\hline & & CssbCS6R & GTA CCA GAC GAA TAT CCG CTA TTA & \\
\hline \multirow[t]{2}{*}{ CS3 } & $\operatorname{cst} A$ & CS3F1 & GGTCTTCACTGTCAGCTATGAGTT & 136 \\
\hline & & CS3R1 & TAATGTTAAATTATCCTGAGGAGCC & \\
\hline \multirow[t]{2}{*}{ CS5 } & $\operatorname{csfA}$ & CS5F1 & GCGTGACACGTCAGCTAATATAAAC & 235 \\
\hline & & CS5R & GGCATTCATATCAATAGAAATATGAGAC & \\
\hline \multirow[t]{2}{*}{ CS7 } & $\operatorname{csv} A$ & CS7F & TGCTCCCGTTACTAAAAATACG & 418 \\
\hline & & CS7R & GGCATTCATATCAATAGAAATATGAGAC & \\
\hline \multirow[t]{2}{*}{ CS2 } & $\cot A$ & $\mathrm{CS} 2 \mathrm{~F}$ & TCTGCTCGTATCAATACCCAAGTT & 140 \\
\hline & & CS2R & GTGCCAGCGAATGAAACCTCTAAA & \\
\hline \multirow[t]{2}{*}{ CS17/19 } & $\operatorname{csb} A$ and $\operatorname{cs} d A$ & mpcr GP3 & ACTCTRTCGCATTAACCTATTCT & 169 \\
\hline & & CS17_19R & GTCACTTTCATCGGAATTTGCGAG & \\
\hline \multirow[t]{2}{*}{ CS21 } & $\operatorname{lng} A$ & CS21F & TATGAGCCTKCTGGAAGTYATCAT & 292 \\
\hline & & CS21R & GTTATTACGCACTTCGTCTGGT & \\
\hline \multirow[t]{2}{*}{ CS1/PCF071 } & $\operatorname{csO} A$ & mpcr gp3 & ACTCTRTCGCATTAACCTATTCT & 334 \\
\hline & & CS1_PCFO71R & CCCTGATATTGACCAGCTGTTAGT & \\
\hline
\end{tabular}

The ETEC CFs screening was performed in three separate PCR master mixes: master mix I for detection of CFA/l, CS4, CS6 and CS14 genes, master mix II for detection of CS3, CS5 and CS7 genes and master mix III for detection of CS2, CS17/19, CS21 and CS1/PCF071 genes

\section{Results}

Distribution of children across the age groups

Of the 225 children whose $E$. coli isolates were analyzed in this study, 39 (17.3\%), 44 (19.6\%), 50 (22.2\%), 61 $(27.1 \%)$ and $31(13.8 \%)$ were aged $1-12$ months, $>12-$ 24 months, $>24-36$ months, $>36-48$ months and $<48$ $<60$ months respectively (Table 2 ). The mean age of the study participants providing the randomly selected archived $E$. coli isolates was 31 months.

\section{Distribution of ETEC across the age groups}

Of the $225 \mathrm{E}$. coli isolates characterized, 23 (10.2\%) were positive for ETEC. The fraction of ETEC isolates were similar in each age group with a majority detected in children aged $>36-48$ months old. (Table 2). There was no significant difference in the distribution of ETEC across age groups $(p=0.978)$.

\section{Detection of ETEC toxins and CFs across the age groups}

Heat stable toxin (ST) gene was the most common detected in 16 (69.6\%). Heat labile toxin (LT) gene was detected in $5(21.7 \%)$ of the ETEC isolates. Both ST and LT toxins genes were detected in $2(8.7 \%)$ of the isolates. Majority $5(31.25 \%)$ of ETEC with ST gene were detected in children aged $>36-48$ months old whileETEC LT gene were equally detected 1 (20\%) across all the age groups. ETEC with both LT/ST genes were equally detected $1(50 \%)$ in children aged $<12-24$ months and $>$ 36-48 months.

We detected CF genes in 14 (60.9\%) of the ETEC isolates. CS6 6 (42.9\%) was the most common followed by 
Table 2 Age distribution of children with acute diarrhea associated with ETEC

\begin{tabular}{lll}
\hline Age (months) & Number (\%) children with diarrhea & Number (\%) of ETEC positive children \\
\hline $1-12$ & $39(17.3)$ & $4(10.3)$ \\
$>12-24$ & $44(19.6)$ & $5(11.4)$ \\
$>24-36$ & $50(22.2)$ & $4(8.0)$ \\
$>36-48$ & $61(27.1)$ & $7(11.5)$ \\
$>48-<60$ & $31(13.8)$ & $3(9.7)$ \\
Total & 225 & $23(10.2)$
\end{tabular}

A majority of the $E$. coli isolates were isolated from children aged between $>36-48$ months old

a combination of $\mathrm{CFA} /+\mathrm{CS} 21$ genes at $3(21.4 \%)$. CS14, CS3, CS7 and a combination of CS5 + CS6, CS2 + CS3 genes were detected equally in 1 (7.1\%) ETEC isolate each. CFA/I, CS4, CS5, CS2, CS17/19, CS1/PCFO71 and CS21 genes were not detected. Each age group had at least one CF detected from the ETEC isolates. Out of the $11 \mathrm{CFs}$ we screened for we did not detect CF genes in 9 (39.1\%) ETEC isolates.

\section{Association of CFs with toxin types}

The association of CFs genes differed by ETEC toxin. More CF genes were detected in 11 (78.6\%) ETEC- ST while $2(14.3 \%)$ and 1 (7.1\%) CF were detected in ETEC$\mathrm{LT}$ and ETEC-LT/ST respectively. In a majority of ETEC-ST we detected CS6. In ETEC -LT, we detected only CS6 and CS7 while in ETEC-LT/ST we detected only CS3. Among the 9 (39.1\%) ETEC isolates that lacked an identifiable CF, $3(60 \%)$ were ETEC-LT, 5 (44.5\%) were ETEC-ST and 1 (50\%) were ETEC -LT/ST.

\section{Discussion}

Enterotoxigenic E. coli is a major cause of diarrhea in children below 5 years of age and travelers in less developed and developing countries. In our study, the proportion of ETEC in children under the age of 5 years with acute diarrhea positive for E.coli was $10.2 \%$. This finding is close to the proportions reported in a study in Machakos, Kenya [13] and in Bolivia [22] at 11 and 9.2\% respectively. Two studies in Indonesia reported higher proportions of 19\% [7] and 14.9\% [23] while Bangladesh reported $14 \%$ [24]. The variation between our finding and these studies could be due to the differences in primers used, geographical factors, target population and number of samples tested.

In our study, we identified that the ST as the most common toxin gene, detectedin 16 (69.6\%) of ETEC strains followed by LT detected in $5(21.7 \%)$ while 2 (8.7\%) had both LT and ST toxins genes. These findings are consistent with a study in Indonesia where ST toxin was the most common followed by LT while LT/ST genes were the least [23]. A similar finding was also reported in a study across four regions of the world and the Global Enteric Multicenter Study where ST was the most frequent toxin $[25,26]$. However, these findings are not in agreement with reports of a study in Nigeria where ST and LT toxins were detected equally among the ETEC isolates [8]. Additionally, a study in Bolivia reported that LT was the most common toxin followed by LT/ST and the least was ST. [22].

We detected CFs genes in $60.9 \%$ of the ETEC strains similar to a study in Peru where it was detected at $65 \%$ [27] but lower than $80 \%$ reported by Kharat et al. [25]. Our finding is higher than the finding in studies carried out in Nigeria (43.7\%), Brazil (50\%) and Indonesia (18.2\%) [7, 8, 28]. CS6 was the most detected CFs in our study. This is consistent with finding from a study by [Simuyandi et al. [12], Qadri et al. [24], Taxt et al. [29], Blackburn et al. [30]] where CS6 was the most common CF but contrasts to a study in Kenya where the CFA/I was the most common followed by CS6 [13]. In Bolivia CFA/I was the most common followed by CS17 [22]. A study by Kharat et al. [25] reported that CS21 was the most common followed by CS6. The difference between our findings and those from other studies may be due to the difference in the expression of CFs by ETEC in different geographical regions, the difference in the laboratory methods/ primers employed in the identification of CFs [28]. Additionally, loss of plasmids carrying the CFs could be another reason for the differences [13].

In our study 9 (39.1\%) of ETEC lacked an identifiable CF. This observation is consistent with the finding in Kenya [13] that reported $36.7 \%$ of ETEC without an identifiable CF. Studies in Egypt reported approximately $50 \%$ of ETEC isolates lacked an identifiable CF [31, 32]. The lack of an identifiable CF could be explained by the following reasons; loss of plasmid harboring the CFs genes due to repeated sub culturing or long-term storage; down regulation of CF genes; a mutation within the genetic locus; expression of a CF not covered by the primers used in the PCR panel and CFs that are unknown and have not been classified [7, 13, 23, 28]. The lack of CF has been reported to be mainly related to LT strains $[8,13,27,32]$ which is consistent with our results where $60 \%$ of the LT strains lacked a detectable CF. However, some studies have reported that CFs is almost 
equally associated with LT and ST-positive ETEC strains $[8,28]$.

\section{Conclusion}

This study documents the detection of ETEC in children under the age of 5 years with acute diarrhea from a government-run community hospital in Kenya. ETEC producing ST was the most common strain in children with acute diarrhea. CS6 was the most common CF and that more CFs were detected from the ETEC strains producing ST. These results, and their variation from others published in other low- and low- to middle-income countries, emphasize the value of continuous identification of ETEC toxins and colonization factors in different regions and populations in Kenya so as to better inform the prevalence and vaccine development strategies. Development of an ETEC vaccine is dependent on an indepth understanding of toxins and CF distribution. Our results provide useful information on ETEC virulence factors both toxins and colonization factors that can be considered as among the targets in the development of an ETEC vaccine.

\section{Limitations of the study}

While this is the first report to characterize ETEC for STp and CFs genes from KTRH diarrheal samples from children under five, in this study we did not test for non-classical virulence genes of ETEC and all the CFs that have been described. We did not also look into antibiotic resistance patterns of the ETEC detected. However, the results do follow trends seen in other studies.

\section{Future research}

There is need to carry out further research to test for non-classical virulence genes of ETEC to determine how ETEC strains that lack an identifiable CFs are able to cause diarrhea especially in children under 5 years. Also, we recommend that future studies should include asymptomatic children to enable a more conclusive finding on the burden of ETEC in terms of toxins and CFs on children below the age of 5 years.

\footnotetext{
Abbreviations

CF: Colonization factor; CFA: Colonization factor antigen; CS: Coli surface; ${ }^{\circ} \mathrm{C}$ : Degree centigrade; DNA: Deoxyribonucleic acid; E. coli: Escherichia coli; EPS: Enteric Pathogens Surveillance; ETEC: Enterotoxigenic Escherichia coli; KEMRI-SERU: Kenya Medical Research Institute Scientific Ethical Review Unit; KTRH: Kisii Teaching and Referral Hospital; LT: Heat labile toxin; MHK: Microbiology Hub Kericho; PCR: Polymerase chain reaction; rpm: Revolution per minute; spp: Species; ST: Heat stable toxin; STh: Heat stable toxin of human origin; STp: Heat stable toxin of porcine origin; USAMRD-A/K: United States Army Medical Research Directorate Africa/Kenya; $\mu$ : Microliter; UV: Ultraviolet; \%: Percentage
}

\section{Acknowledgements}

We acknowledge the Naval Health Research Center (SanDiego, CA, USA) for providing positive controls strains that were used in this study.

\section{Authors' contributions}

EK contributed to the study design, laboratory testing, data analysis and drafting of the manuscript. EO, ID, AF and JK contributed in the study design and manuscript review. CP, NK, RK, JN, MK, AR and $A O$ contributed in manuscript review. All authors read and approved the final manuscript.

\section{Authors' information}

Erick Kipkirui, Cliff Philip, Nancy Kipkemoi, Ronald Kirera, Janet Ndonye, Mary Kirui, Abigael Ombogo, Margaret Koech, Elizabeth Odundo and Dr. Ibrahim Daud are all employees at the United States Army Medical Research

Directorate-Africa. Janeth Kombich is a senior lecturer at the University of Kabianga, Kenya. Alexander Flynn was previously affiliated to United States Army Medical Research Directorate -Africa but is currently affiliated to Walter Reed Army Institute of Research, Silver Spring, USA. Amanda Roth is the current laboratory director of the Microbiology Hub Kericho.

\section{Funding}

Funding was provided by the Armed Forces Health Surveillance Division, Global Emerging Infections Surveillance Branch (GEIS), FY2019 Promis ID P152_20_KY_14. The funding agency had no role in the design of the study, data collection, analysis and interpretation of data or writing the manuscript.

Availability of data and materials

All the data generated or analyzed during this study are included in this published article.

\section{Declarations}

Ethics approval and consent to participate

Ethical clearance to carry out this study was obtained from Kenya Medical Research Institute Scientific and Ethical Unit (KEMRI-SERU) and Walter Reed Army Institute of Research (WRAIR) institutional review boards (IRBs) and designated KEMRI/SERU/CCR/0167/4000 and WRAIR\#2728 respectively. It was determined that it did not involve interaction with human subjects and that consent to participate was adequately covered by the parent protocol WRAIR\#1549.

\section{Consent for publication}

Consent for publication was sought from all authors, institutional review boards. Material has been reviewed by the Walter Reed Army Institute of Research. There is no objection to its presentation and or publication. The opinions or assertions contained herein are the private views of the author and are not to be construed as official, or reflecting true views of the Department of the Army or the Department of Defense. The investigators have adhered to the policies for the protection of human subjects as prescribed in AR 70-25. This work has been published with the permission of the USAMRD-A, WRAIR and Director of KEMRI.

\section{Competing interests}

The authors declare that they have no competing interests.

\section{Author details}

'United States Army Medical Research Directorate-Africa/Kenya, Nairobi, Kenya. ${ }^{2}$ Walter Reed Army Institute of Research, Silver Spring, USA.

${ }^{3}$ University of Kabianga, Kericho, Kenya.

Received: 16 April 2021 Accepted: 13 September 2021

Published online: 15 December 2021

References

1. Mokomane M, Kasvosve I, de Melo E, Pernica JM, Goldfarb DM. The global problem of childhood diarrhoeal diseases: emerging strategies in prevention and management. Ther Adv Infect Dis. 2018;5(1):29-43. https:// doi.org/10.1177/2049936117744429.

2. Ugboko HU, Nwinyi OC, Oranusi SU, Oyewale JO. Childhood diarrhoeal diseases in developing countries. Heliyon. 2020;6(4):e03690. https://doi.org/1 0.1016/j.heliyon.2020.e03690.

3. Khalil IA, Troeger C, Blacker BF, Rao PC, Brown A, Atherly DE, Brewer TG, Engmann CM, Houpt ER, Kang G, Kotloff KL, Levine MM, Luby SP, MacLennan CA, Pan WK, Pavlinac PB, Platts-Mills JA, Qadri F, Riddle MS, Ryan ET, Shoultz DA, Steele AD, Walson JL, Sanders JW, Mokdad AH, Murray CJL, 
Hay SI, Reiner Jr RC Morbidity and mortality due to shigella and enterotoxigenic Escherichia coli diarrhoea: the global burden of disease study 1990-2016 [published correction appears in Lancet Infect Dis. 2018 Oct 30:]. Lancet Infect Dis 2018;18(11):1229-1240. doi:https://doi.org/10.101 6/S1473-3099(18)30475-4.

4. Kotloff KL, Nataro JP, Blackwelder WC, Nasrin D, Farag TH, Panchalingam S, et al. Burden and aetiology of diarrhoeal disease in infants and young children in developing countries (the Global Enteric Multicenter Study, GEMS): a prospective, case-control study. Lancet. 2013;382(9888):209-22. https://doi.org/10.1016/50140-6736(13)60844-2.

5. Goldsmid JM, Leggat PA. The returned traveler with diarrhea. Aust Fam Physician. 2007;36(5):322-7.

6. PATH and Bio Ventures for Global Health. https://path.azureedge.net/media/ documents/NAC-etec-investment-rpt.pdf. Accessed on 12 Apr 2020.

7. Oyofo BA, Subekti DS, Svennerholm AM, et al. Toxins and colonization factor antigens of enterotoxigenic Escherichia coli among residents of Jakarta, Indonesia. Am J Trop Med Hyg. 2001;65(2):120-4. https://doi.org/1 0.4269/ajtmh.2001.65.120

8. Ifeanyichukwu CIC, Ikeneche NF, Bassey BE, Al-Gallas N, Alexander CA, et al. Characterization of toxins and colonization factors of Enterotoxigenic Escherichia coli isolates from children with acute diarrhea in Abuja, Nigeria. Jundishapur J Microbiol. 2018;1 1(1):e64269. https:/doi.org/10.5812/jjm.64269.

9. Wang H, Zhong Z, Luo Y, Cox E, Devriendt B. Heat-stable enterotoxins of enterotoxigenic Escherichia coli and their impact on host immunity. Toxins (Basel). 2019;11(1):24. https://doi.org/10.3390/toxins11010024.

10. Zhang W, Berberov EM, Freeling J, He D, Moxley RA, Francis DH. Significance of heat-stable and heat-labile enterotoxins in porcine colibacillosis in an additive model for pathogenicity studies. Infect Immun. 2006;74(6):3107-14. https://doi.org/10.1128/IAl.01338-05.

11. Duan Q, Xia P, Nandre R, Zhang W, Zhu G. Review of newly identified functions associated with the heat-labile toxin of enterotoxigenic Escherichia coli. Front Cell Infect Microbiol. 2019;9:292. https://doi.org/10.3389/fcimb.201 9.00292 .

12. Simuyandi M, Chilengi R, Connor SB, Voeglein JB, Laban NM, Kazimbaya KM, et al. Enterotoxigenic Escherichia coli toxins and colonization factors among Zambian children presenting with moderate to severe diarrhea to selected health facilities. Arch Microbiol Immunol. 2019;3:173-84.

13. Juma BW, Waiyaki PG, Bulimo WD, Wurapa MMM, Kariuki S. Molecular detection of Enterotoxigenic Escherichia coli surface antigens from patients in Machakos District Hospital, Kenya. ECAMJ. 2014;1(2):62-8

14. lijima Y, Oundo JO, Hibino T, Saidi SM, Hinenoya A, Osawa K, et al. High prevalence of diarrheagenic Escherichia coli among children with diarrhea in Kenya. Jpn J Infect Dis. 2017;70(1):80-3. https://doi.org/10.7883/yoken. JID.2016.064.

15. Swierczewski BE, Odundo EA, Koech MC, Ndonye JN, Kirera RK, Odhiambo $C P$, et al. Enteric pathogen surveillance in a case-control study of acute diarrhoea in the town of Kisii, Kenya. J Med Microbiol. 2013;62(Pt 11):17746. https://doi.org/10.1099/jmm.0.059139-0.

16. Swierczewski BE, Odundo EA, Koech MC, Ndonye JN, Kirera RK, Odhiambo $\mathrm{CP}$, et al. Surveillance for enteric pathogens in a case-control study of acute diarrhea in Western Kenya. Trans R Soc Trop Med Hyg. 2013;107(2):83-90. https://doi.org/10.1093/trstmh/trs022.

17. Pavlinac PB, John-Stewart GC, Naulikha JM, Onchiri FM, Denno DM, Odundo EA, et al. High-risk enteric pathogens associated with HIV infection and HIV exposure in Kenyan children with acute diarrhoea. AIDS. 2014;28(15):228796. https://doi.org/10.1097/QAD.0000000000000396.

18. Brooks JT, Ochieng JB, Kumar L, Okoth G, Shapiro RL, Wells JG, et al. Surveillance for bacterial diarrhea and antimicrobial resistance in rural western Kenya, 1997-2003. Clin Infect Dis. 2006;43(4):393-401. https://doi. org/10.1086/505866.

19. Brander RL, Walson JL, John-Stewart GC, Naulikha JM, Ndonye J, Kipkemoi $\mathrm{N}$, et al. Correlates of multi-drug non-susceptibility in enteric bacteria isolated from Kenyan children with acute diarrhea. PLoS Negl Trop Dis. 2017;11(10):e0005974. https://doi.org/10.1371/journal.pntd.0005974.

20. Naing L, Winn T, Rusli BN. Practical issues in calculating the sample size for prevalence studies. Arch Orofac Sci. 2006;1:9-14.

21. Nada RA, Shaheen HI, Touni I, Fahmy D, Armstrong AW, Weiner M, et al. Design and validation of a multiplex polymerase chain reaction for the identification of enterotoxigenic Escherichia coli and associated colonization factor antigens. Diagn Microbiol Infect Dis. 2010;67(2):134-42. https://doi. org/10.1016/j.diagmicrobio.2010.01.011.
22. Rodas C, Mamani R, Blanco J, Blanco JE, Wiklund G, Svennerholm AM, et al. Enterotoxins, colonization factors, serotypes and antimicrobial resistance of enterotoxigenic Escherichia coli (ETEC) strains isolated from hospitalized children with diarrhea in Bolivia. Braz J Infect Dis. 2011;15(2):132-7. https:// doi.org/10.1016/s1413-8670(11)70158-1.

23. Subekti DS, Lesmana M, Tjaniadi P, Machpud N, Sriwati, Sukarma, et al. Prevalence of enterotoxigenic Escherichia coli (ETEC) in hospitalized acute diarrhea patients in Denpasar, Bali, Indonesia. Diagn Microbiol Infect Dis. 2003;47(2):399-405. https://doi.org/10.1016/S0732-8893(03)00120-2.

24. Qadri F, Das SK, Faruque AS, et al. Prevalence of toxin types and colonization factors in enterotoxigenic Escherichia coli isolated during a 2year period from diarrheal patients in Bangladesh. J Clin Microbiol. 2000; 38(1):27-31. https://doi.org/10.1128/JCM.38.1.27-31.2000.

25. Kharat VB, Ahmed M, Jiang ZD, Riddle MS, DuPont HL. Colonization factors in Enterotoxigenic Escherichia coli strains in travelers to Mexico, Guatemala, and India compared with children in Houston, Texas. Am J Trop Med Hyg. 2017:96(1):83-7. https://doi.org/10.4269/ajtmh.16-0405.

26. Isidean SD, Riddle MS, Savarino SJ, Porter CK. A systematic review of ETEC epidemiology focusing on colonization factor and toxin expression. Vaccine. 2011;29(37):6167-78. https://doi.org/10.1016/j.vaccine.2011.06.084.

27. Rivera FP, Ochoa TJ, Maves RC, Bernal M, Medina AM, Meza R, et al. Genotypic and phenotypic characterization of enterotoxigenic Escherichia coli strains isolated from Peruvian children. J Clin Microbiol. 2010;48(9): 3198-203. https://doi.org/10.1128/JCM.00644-10.

28. Nunes MR, Penna FJ, Franco RT, Mendes EN, Magalhães PP. Enterotoxigenic Escherichia coli in children with acute diarrhoea and controls in Teresina/PI, Brazil: distribution of enterotoxin and colonization factor genes. J Appl Microbiol. 2011;111(1):224-32. https://doi.org/10.1111/j.1365-2672.2011. 05031.x.

29. Taxt A, Aasland R, Sommerfelt H, Nataro J, Puntervoll P. Heat-stable enterotoxin of enterotoxigenic Escherichia coli as a vaccine target. Infect Immun. 2010;78(5):1824-31. https://doi.org/10.1128/IAl.01397-09.

30. Blackburn D, Husband A, Saldaña Z, et al. Distribution of the Escherichia coli common pilus among diverse strains of human enterotoxigenic E. coli. J Clin Microbiol. 2009;47(6):1781-4. https://doi.org/10.1128/JCM.00260-09.

31. Rao MR, Abu-Elyazeed R, Savarino SJ, Naficy AB, Wierzba TF, Abdel-Messih I, et al. High disease burden of diarrhea due to enterotoxigenic Escherichia coli among rural Egyptian infants and young children. J Clin Microbiol. 2003:41(10):4862-4. https://doi.org/10.1128/JCM.41.10.4862-4864.2003.

32. Shaheen HI, Khalil SB, Rao MR, Abu Elyazeed R, Wierzba TF, Peruski LF Jr, et al. Phenotypic profiles of enterotoxigenic Escherichia coli associated with early childhood diarrhea in rural Egypt. J Clin Microbiol. 2004;42(12):558895. https://doi.org/10.1128/JCM.42.12.5588-5595.2004.

\section{Publisher's Note}

Springer Nature remains neutral with regard to jurisdictional claims in published maps and institutional affiliations.

Ready to submit your research? Choose BMC and benefit from:

- fast, convenient online submission

- thorough peer review by experienced researchers in your field

- rapid publication on acceptance

- support for research data, including large and complex data types

- gold Open Access which fosters wider collaboration and increased citations

- maximum visibility for your research: over $100 \mathrm{M}$ website views per year

At $\mathrm{BMC}$, research is always in progress.

Learn more biomedcentral.com/submission 